\title{
Crushed by the Wheels of Industry: War, Heroes, and Domestic Recolonization in the Time of Covid-19
}

\author{
Albin Wagener ${ }^{1}$ \\ Published online: 4 June 2020 \\ (C) Springer Nature Switzerland AG 2020
}

Keywords Neoliberalism · Heroes · System · Society · Nature · Exploitation · Postdigital

\section{The Creation of War}

From France to India, from Germany to Italy, from the USA to China, the political answer to the Covid-19 crisis has been to temporary restrict some human rights. Political actors across the globe, such as the OECD (Gurría 2020), the French Republic (Macron 2020), and the United Nations (Guterres 2020), have compared the pandemic to war, using this well-known rhetoric to justify their economic and political actions. The pandemic requires a coordinated and measured response, yet do we really need to add the metaphor of war to the ambient stress?

Flusberg et al. (2018: 9) explain that war metaphors are used to 'capture people's attention, trigger emotional responses, tap into a rich source of schematic knowledge, and lead people to take a stand and form particular opinions on a wide range of issues.' In a cognitive and semantic perspective (Wagener 2019), war is an easy conveyor of meaning: unfortunately, every citizen knows what war is or has an idea of what war could be. War is always against someone or something; it draws a line between the good (us) and the bad (them). This dichotomy leaves no room for ethical complexity. Every political action is aimed at winning. Any criticism becomes inaudible or suspicious: if you are not with us, you are against us. Using the war metaphor makes it easier to understand the Covid-19 pandemic, yet it also reduces our potential political choices for action.

On the opposite side, there is always an enemy.

Enemy images, and enemies, are made by accusations, condemnations, and denunciations. This war propaganda, or war talk, is psychological preparation

Albin Wagener

albin.wagener@gmail.com

1 University of Rennes 2 / INALCO, 13 rue de Bruxelles, 49000 Angers, France 
for war, whether intended as such or not. (...) War talk assumes superiority of one position over another, to the point where it seems worth killing and dying if we cannot get what we want. (Eckhardt 1991: 94).

Global political elites are using war talk to prepare populations for economic and democratic measures that may threaten basic citizen rights (Maillat 2013). But it is difficult to picture being at war with an organism at the edge of life, that is not even aware of the war or probably of its own existence. Can the coronavirus be fought using conventional means of war? Why did we not declare war at other illnesses that also kill thousands of people? Is the coronavirus our real enemy; are we actually fighting against its place of origin, globalization, or the neoliberal system itself? Answers to these questions may not even matter: war itself is perhaps more important than the enemy or its outcome.

\section{Turning Victims into Heroes}

Every war needs heroes. According to Kinsella et al. (2015: 2), '[h]eroes are described in the literature as uplifting and enhancing the lives of others. Heroes may arouse positive emotions such as awe, gratitude, or admiration. (...) Three broad categories of hero functions are accounted for: enhancing, moral modeling, and protecting.' During Covid19 lockdowns, professions such as teachers and computer programmers quickly switched to working online, while healthcare workers, nurses, garbage collectors, delivery people, and many others had to remain in their physical workplaces. This is a truly postdigital event: digital privilege offers health protection, but not for all workers, thus creating an important new divide between 'necessary' and 'non-necessary' workers (Jandrić 2020).

Their inability to work from home transforms these predominantly low-wage workers (Ray and Rojas 2020; Kazis and Miller 2001) into heroes-they are exposed to the virus, so that the rest of the population can safely remain in their homes. Before the lockdown, Schnipper (2008: 90; see also Csikszentmihalyi, Condren, and Lebuda 2017) called these people everyday heroes: 'Their only option is to "keep on keeping on," and their only choice is in how they do so.' During the lockdown, however, not all heroes have remained in streets and hospitals; some of them work from small apartments, perhaps exposed to domestic violence, or trapped within mental issues.

We need clean streets, we need our goods delivered, and we need to remain healthy. Neoliberalism needs healthy workers that 'keep on keeping on,' especially in the face of crisis. Everyday heroes of the Covid-19 lockdown are not just our saviors, they are also victims of our social system. These people often see themselves as victims rather than heroes (Hill and Brunsden 2009). Our neoliberal societies have organized a celebration of victims of the Covid-19 pandemic, which is also a celebration of necessary casualties of the system itself and a celebration against change, developed to avoid important questions such as economic recognition of low-wage (necessary) workers.

\section{Crushed by the Wheels of Industry}

The concept of 'hero' is a cheap social token thrown at the most exploited victims of neoliberalism. Their exploitation takes place within modern democracy, which has 
thusly transformed into a neoliberal fantasy (Dean 2009). The neoliberal fantasy dives into ontopolitics (Dormeau 2019) and fuels on the control of our psychological wellbeing and the so-called happycracy (Cabanas and Illouz 2018). The coronavirus crisis has little to do with individual health; it exposes ways in which healthcare systems have been thoroughly and gradually damaged by decades of neoliberal policies. Yet, many responses to the coronavirus crisis are expressed through digital devices of controlling individual bodies and their various imprints such as surveillance applications (Kamel Boulos and Geraghty 2020; Calvo, Deterding, and Ryan 2020).

Not all victims are transformed into heroes. Some workers, especially those in the field of culture, are seen as being less essential than others. (Culture should not be equated with entertainment, which distracts citizens from social and economic issues, and which thrives during the lockdown.) Those seen as essential victims (such as nurses) are recognized through a discursive token of heroes, and those seen as less essential victims (such as cultural workers) remain abandoned. This creates a hierarchy of victims.

Neoliberal societies are modern offspring of colonial capitalism (Blaut 1989). Through ontopolitics, neoliberalism continues to colonize various aspects of our daily lives, such as our will to have a successful career, our desire to remain healthy, and our struggle for happiness.

I posit the idea that each individual intrinsically owns a self-alienating and selfconsenting part; this part makes them permeable and potentially reactive to every 'stimuli-reaction' scheme on which they are deliberately drawing. Thus the main strength of neoliberalism might not be to submit individuals via self-optimizing orders that have been internalized by people, but rather to build tailor-made frames: individuals voluntarily submit themselves to said frames by making themselves cognitively and affectively available for the reception of each and every stimulus of their context. (Dormeau 2019: 142). ${ }^{1}$

Labelling some of its own victims as heroes, neoliberalism recolonizes professions that it has abandoned. In the context of ubiquitous war talk, this can be explained through the concept of état de siege which is central to colonial capitalism (Prakash 1996).

This conception of colonial capitalism allows us to see a unifying principle between the racialization, domination, and exploitation of people and the alienation, domination, and exploitation of resources. It invites us to understand the observed similarity in the patterns of ecological and colonial crisis as the product of a unified logic of capitalist exploitation that makes them obey a similar tempo and follow similar trajectories. (Hage 2016: 47)

In order to fight potential colonization by the virus, capitalist societies recolonize their democratic roots using the political force of lockdown, imposing the idea that survival of capitalist economy is far more important than democracy. 'It is not merely a question

\footnotetext{
$\overline{{ }^{1} \text { Author's translation from French. }}$
} 
of failed borders and failed governmentality, but a question of the inability to make sense of and negotiate a relation with ungovernable beastly "entities", human and nonhuman, that the era of permanent overcolonization has thrown at the Western world.' (Hage 2016: 48) Hage's pre-Covid-19 analysis refers to crises linked to international migrations and ecological threats, yet the principle remains. Neoliberal democracies are now facing an ungovernable threat which, according to Hage, represents the return of Gaia: even a tiny virus, at the border between organic and inorganic matter, can threaten the whole humankind.

A fantasy that the humankind can dominate and exploit nature without consequences is at the core of Western colonial capitalism and neoliberal democracy (Tabb 1974). In order to prevent transformation of the Covid-19 health crisis into a social crisis, political elites recolonize their own population by unifying them against a common enemy, using 'us vs. them' war rhetoric and glorifying 'useful' heroes. While this symbolic strategy works quite well in the face of adversity, the health crisis is dialectically intertwined with global capitalist and colonialist exploitation reflexes (Crook, Short, and South 2018), and shows that postcolonialism, in terms of democratic policies, has yet to happen (Porr and Matthews 2017).

Covid-19 is an emergence of nature in the face of capitalist colonialism, triggering global feelings of besiegement and war-like political responses. But in the coronavirus pandemic, there is no war, there are no heroes, and there is no enemy. These discursive representations are merely powerful (Ng and Bradac 1993), socially constructed (Van Leeuwen 2009), and mediated social rapports (Kopytowska 2015). Neoliberal democracies now engage in language games (Wagener 2020) which allow them follow the same doxa (Sarfati 2011) while wearing seemingly different masks (Wagener 2018, 2019). In the face of the coronavirus pandemic, the rhetoric of war and heroes allows the system (Meunier 2003) to remain unchanged.

\section{References}

Blaut, J. M. (1989). Colonialism and the rise of capitalism. Science \& Society, 53(3), 260-296.

Cabanas, E., \& Illouz, E. (2018). Happycratie: Comment l'Industrie du Bonheur a Pris le Contrôle de nos Vies. Paris: Premier Parallèle.

Calvo, R. A., Deterding, S., \& Ryan, R. M. (2020). Health surveillance during Covid-19 pandemic. The BMJ, 369, m1373. https://doi.org/10.1136/bmj.m1373.

Crook, M., Short, D., \& South, N. (2018). Ecocide, genocide, capitalism and colonialism: consequences for indigenous peoples and glocal ecosystems environments. Theoretical Criminology, 22(3), 298-317. https://doi.org/10.1177/1362480618787176.

Csikszentmihalyi, M., Condren, M., \& Lebuda, I. (2017). Deviant heroes and social heroism in everyday life. In S. T. Allison, G. R. Goethals, \& R. M. Kramer (Eds.), Handbook of heroism and heroic leadership (pp. 249-261). New York: Routledge.

Dean, J. (2009). Democracy and other neoliberal fantasies: communicative capitalism and left politics. Durham, NC: Duke University Press.

Dormeau, L. (2019). Histoire d'Emotions Néolibérales: Pédagogie d'une Emancipation Individuelle, Dialectique d'une Aliénation Collective. Cahiers d'histoire, XXXVI, 2, 129-149. https://doi.org/10.7202 /1066848ar.

Eckhardt, W. (1991). Making and breaking enemy images. Bulletin of Peace Proposals, 22(1), 87-95. https://doi.org/10.1177/096701069102200110.

Flusberg, S., Matlock, T., \& Thibodeau, P. (2018). War metaphors in public discourse. Metaphor and Symbol, 33(1), 1-18. https://doi.org/10.1080/10926488.2018.1407992. 
Gurría, A. (2020). Coronavirus (Covid-19): joint actions to win the war. OECD. https://www.oecd. org/about/secretary-general/Coronavirus-COVID-19-Joint-actions-to-win-the-war.pdf. Accessed 15 May 2020.

Guterres, A. (2020). This war needs a war-time plan to fight it. UN Secretary-General's Remarks at G-20 Virtual Summit on the Covid-19 Pandemic. United Nations, 26 March. https://www.un. org/en/coronavirus/war-needs-war-time-plan-fight-it. Accessed 15 May 2020.

Hage, G. (2016). Etat de Siège: a dying domesticating colonialism? American Ethnologist, 43(1), 38-49. https://doi.org/10.1111/amet.12261.

Hill, R., \& Brunsden, V. (2009). 'Heroes' as victims: role reversal in the fire and rescue service. The Irish Journal of Psychology, 30(1-2), 75-86. https://doi.org/10.1080/03033910.2009.10446299.

Jandrić, P. (2020). Postdigital research in the time of COVID-19. Postdigital Science and Education, 2(2), 233-238. https://doi.org/10.1007/s42438-020-00113-8.

Kamel Boulos, M. N., \& Geraghty, E. M. (2020). Geographical tracking and mapping of coronavirus disease Covid-19 / severe acute respiratory syndrome coronavirus 2 (SARS-CoV-2) epidemic and associated events around the world: how $21^{\text {st }}$ century GIS technologies are supporting the global fight against outbreaks and epidemics. International Journal of Health Geographics, 19(1), 8. https://doi.org/10.1186 /s12942-020-00202-8.

Kazis, R., \& Miller, M. S. (2001). Low-wage workers in the new economy. Washington: The Urban Institute Press.

Kinsella, E. L., Ritchie, T. D., \& Igou, E. R. (2015). Lay perspectives on the social and psychological functions of heroes. Frontiers in Psychology, 6(130), 1-12. https://doi.org/10.3389/fpsyg.2015.00130.

Kopytowska, M. (2015). Mediating identity, ideology and values in the public sphere: towards a new model of (constructed) social reality. Lodz Papers in Pragmatics, 11(2), 133-156. https://doi.org/10.1515/lpp2015-0008.

Macron, E. (2020). Adresse aux Français du Président de la République Emmanuel Macron. Elysee, 16 March. https://www.elysee.fr/emmanuel-macron/2020/03/16/adresse-aux-francais-covid19. Accessed 15 May 2020.

Maillat, D. (2013). Constraining context selection: on the pragmatic inevitability of manipulation. Journal of Pragmatics, 59(2), 190-199. https://doi.org/10.1016/j.pragma.2013.07.009.

Meunier, J. P. (2003). Approches Systémiques de la Communication. Brussels: De Boeck.

Ng, S. H., \& Bradac, J. J. (1993). Power in language. Thousand Oaks, CA: Sage.

Porr, M., \& Matthews, J. M. (2017). Post-colonialism, human origins and the paradox of modernity. Antiquity, 91(358), 1058-1068. https://doi.org/10.15184/aqy.2017.82.

Prakash, G. (1996). Colonialism, capitalism and the discourse of freedom. International Review of Social History, 41(S4), 9-25. https://doi.org/10.1017/S0020859000114257.

Ray, R., \& Rojas, F. (2020). Inequality during the coronavirus pandemic. Contexts. Sociology for the Public, 16 April. https://contexts.org/blog/inequality-during-the-coronavirus-pandemic/. Accessed 15 May 2020.

Sarfati, G. E. (2011). Analyse du Discours et Sens Commun: Institutions de Sens, Communautés de Sens, Doxa, Idéologie. In J. Guilhaumou \& P. Schepens (Eds.), Matériaux Philosophiques pour l'Analyse du Discours (pp. 139-174). Besançon: Presses Universitaires de Franche-Comté.

Schnipper, H. H. (2008). Sisyphus and other everyday heroes. Journal of Psychosocial Oncology, 21(1), 8993. https://doi.org/10.1300/J077v21n01_05.

Tabb, W. L. (1974). Marxian exploitation and domestic colonialism: a reply to Donald J. Harris. The Review of Black Political Economy, 4(4), 69-87.

Van Leeuwen, T. (2009). Discourse as the recontextualization of social practice. In R. Wodak \& R. Meyer (Eds.), Methods of critical discourse analysis (pp. 144-161). London: Sage.

Wagener, A. (2018). A theory of interactional systems: semantic connections and relational contextics. International Journal of Applied Systemic Studies, 8(1), 32-50. https://doi.org/10.1504 /IJASS.2018.091845.

Wagener, A. (2019). Discours et Système. Théorie Syétamique du Discours et Analyse des Représentations. Brussels: Peter Lang.

Wagener, A. (2020). Hypernarrativity, storytelling, and the relativity of truth: digital semiotics of communication and interaction. Postdigital Science and Education, 2(1), 147-169. https://doi.org/10.1007/s42438019-00066-7. 